\title{
Is smaller necessarily better? Effects of small-scale forest harvesting on stream ecosystems
}

\author{
Antoine Lecerf $^{1 *}$, Jean-Marc Baudoin ${ }^{2}$, Anne A. Besson ${ }^{1,3}$, Sylvain Lamothe ${ }^{1}$ \\ and Clément Lagrue ${ }^{1,3}$ \\ ${ }^{1}$ CNRS, INP, UPS, EcoLab - Université de Toulouse, 118 Route de Narbonne, 31062 Toulouse, France \\ 2 The French National Agency for Water and Aquatic Environments (ONEMA), Research and Development Department, \\ avenue du Petit Parc - Le Nadar Hall C, 94300 Vincennes, France \\ 3 Present address: Department of Zoology, University of Otago, Dunedin, New Zealand
}

\author{
Received 27 March 2012; Accepted 19 October 2012
}

\begin{abstract}
Knowledge on ecological impacts of forestry practices on aquatic ecosystems relies almost exclusively on data from large-scale forest harvesting, often involving clearfelling of whole stream catchments. To determine effects associated with less intensive and widespread forest management, we examined the responses of headwater streams to small-scale forest harvesting, including riparian zones adjacent to study reaches but corresponding to less than $5 \%$ of the catchment areas. Stream reaches running through recently (2-4 years) harvested forest patches were paired with and compared with adjacent reaches bordered by mature broadleaf forest. We determined abiotic stream characteristics, invertebrate community structures and abundances, trout size and population densities, and leaf litter breakdown rates in each of these pairs. Harvested reaches were found to have different channel cross-section morphology and greater invertebrate abundances in leaf packs than mature forest reaches. Shifts in the abundance of common invertebrate predators were also attributed to riparian forest harvesting. Litter breakdown rates and brown trout densities did not show any significant difference between harvested and mature forest reaches across the four site pairs, possibly because of nonlinear responses to post-harvest riparian canopy openness. Managers must be aware that small-scale forest harvesting in stream riparian areas is not without consequences for aquatic ecosystems. Whether natural riparian forest openings, such as caused by tree death and blow-down, have similar effects on stream ecosystems is an important question to address if we are to confirm the usefulness of small-scale forestry and improve forest and stream management schemes.
\end{abstract}

Key words: Fish / forest management / leaf litter breakdown / invertebrates / riparian canopy

\section{Introduction}

Forestry can seriously compromise the ecological integrity of forest streams (Broadmeadow and Nisbet, 2004) and the number of catchments affected is expected to increase due to the currently growing demands for wood products (FAO, 2011). Stream ecosystem productivity is sustained by the breakdown of submerged tree leaf litter by detritivorous invertebrates (Wallace et al., 1997). In addition, forest canopy regulates water temperature and solar radiation while terrestrial arthropods that fall into streams are a crucial food source for salmonids (Wipfli, 1997). There is now consistent evidence that large-scale forest harvesting profoundly alters several key components of stream ecosystems such as channel morphology, hydrology, temperature, water chemistry, biodiversity,

\footnotetext{
*Corresponding author: antoine. lecerf@univ-tlse3.fr
}

productivity, paths of energy flow and rates of material processing (e.g., England and Rosemond, 2003; Sweeney et al., 2004; Moore et al., 2005; Kreutzweiser et al., 2008; Zhang et al., 2009; Ely and Wallace, 2010). Overall, evidence indicates that impacts on streambed morphology or hydrology can be reduced by maintaining riparian forest strips along streams (Broadmeadow and Nisbet, 2004). However, riparian forest buffers have proven inefficient in maintaining invertebrate diversity and litter breakdown rate, a vital ecological process in headwater streams (Kreutzweiser et al., 2008; Lecerf and Richardson, 2010). To reduce impacts on stream ecosystems, researchers and managers have considered alternative forest management strategies, such as limiting the proportion of catchment area harvested.

Impacts of forestry on streams are thought to be proportionate to the percentage of the catchment area harvested (Reid et al., 2010). Small-scale harvesting of less 


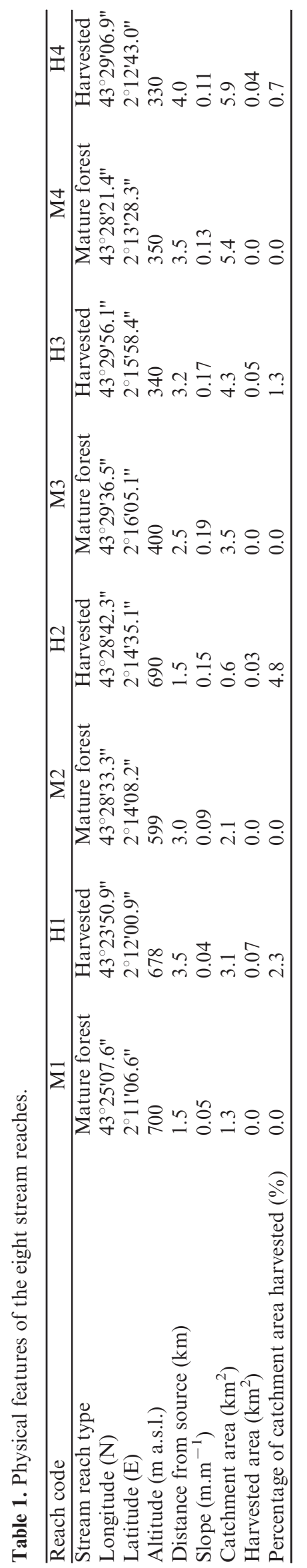

than $5 \%$ of the catchment area should be less detrimental to streams than large-scale clearfelling. However, this remains unclear even though small-scale forest harvesting is a common forestry practice (Harrison et al., 2002). Small harvested areas should result in low inputs of erosion products (ions and solids) and woody debris into streams. Temperature increase due to solar radiations should be limited when only short stream bank lengths are harvested (Moore et al., 2005). Although riparian canopy openings could alter trophic resources available for primary consumers (leaf litter and benthic algae), these effects should be tempered by forest edge shading limiting algal response and the downstream transportation of leaf litter from upstream forested reaches. Finally, the resilience of stream ecosystems to small-scale forest harvesting may not differ markedly from natural causes of local riparian forest openings (e.g., death and blow-down of large trees).

Assessment methods for stream ecosystems affected by forest management are largely based on structural indicators evaluating abiotic habitat characteristics, and the attributes of selected communities and/or populations (Richardson and Thompson, 2009). In contrast, stream functional integrity is not assessed routinely, although functional metrics such as litter breakdown rates have proved to be very sensitive to forest disturbances (Gessner and Chauvet, 2002; Kreutzweiser et al., 2008; Lecerf and Richardson, 2010). In this study, we used structural and functional indicators to compare stream reaches running through a mature deciduous forest with stream reaches affected by small forest harvests (catchment area harvested $<5 \%$ ). We assessed the local effects of small-scale forest management on stream abiotic characteristics, invertebrate communities (structure and abundances), fish populations (densities) and litter breakdown rates.

\section{Materials and methods}

\section{Study sites}

This study was carried out in the Montagne Noire, a $1450-\mathrm{km}^{2}$ highland region about $50 \mathrm{~km}$ east of Toulouse, South-Western France $\left(43^{\circ} 33^{\prime} \mathrm{N}, 1^{\circ} 29^{\prime} \mathrm{E}\right)$. The landscape consists of a mosaic of even-aged pure beech stands (Fagus sylvatica L.), conifer plantations (Picea abies (L.) H. Karst, 1881) and mixed broadleaf forest. We selected eight sites in low-order streams draining small catchment areas situated within a narrow area $(12 \times 7 \mathrm{~km}$; see Table 1 for details). "Harvested" streams (H1-H4; Table 1) were affected by recent (2-4 years old) clear-cutting in both upland and riparian areas (width $>15 \mathrm{~m}$ ). Harvested patches accounted for less than $5 \%$ of the total catchment area and the length of impacted stream reaches was less than $550 \mathrm{~m}$. Harvesting operations were carried out to limit both streambed destruction by harvesting machines and fine sediment contamination of the surface water. No riparian buffer forest strips were left along either side of the streams. Riparian canopy above harvested reaches was 
thus made of early-successional vegetation composed of juvenile and coppiced trees including hazel (Corylus avellana L.), poplars (Populus spp.), alder [A. glutinosa (L) Gaertn.] and willow (Salix spp.), with an undergrowth dominated by blackberries (Rubus spp.). All physical, chemical and biological variables were determined along a 50-m reach taken on the lower third section of each harvested streams. Each harvested reach $(\mathrm{H} 1-\mathrm{H} 4)$ was paired with a corresponding 50-m control reach (M1-M4; Table 1) flowing through mature forest and situated either on an adjacent stream with similar chemical and physical attributes (M1 and M2) or just upstream of the harvested section (M3 and M4). No clear-cut patches were present upstream of the control sites. The control sites were heavily shaded by mature forest made of beech, oak and chestnut, and coppiced alder, hazel and willow.

\section{Riparian canopy}

Stream exposures to sunlight and riparian canopy cover were assessed by determining daytime photosynthetically active radiation (PAR), periphyton biomass and site openness to sky at fully foliated canopy state (JuneOctober). PAR was measured above the water surface on six occasions using a Li250A Photometer (LI-COR, Lincoln, Nebraska, USA). Periphyton biomass was used as an indirect indicator of the sunlight available to benthic algae, which display strong light limitation in forest headwater streams (Kiffney et al., 2003). Ten stones were collected haphazardly from each stream reach in October 2009. The upper surface of each stone was brushed and scraped to remove the periphyton. The chlorophyll-a content of the periphyton was then determined by spectrophotometric measurements and expressed per unit of upper stone area determined from digital pictures (Steinman et al., 2007). Canopy openness was quantified in July 2010 from three hemispherical digital images taken from the stream with a Pentax *ist D camera equipped with a SIGMA $4.5 \mathrm{~mm}$ F2.8 EX DC circular fisheye lens. Gap Light Analyzer v2 (http://www.ecostudies.org/gla/) software was used to assess percent gap area, assuming an equisolid angle projection according to the lens manufacturer's instructions.

\section{Geomorphology}

Streambed characteristics of the reaches studied were assessed from ten equally spaced transects during the lowflow period in July 2010. On each transect, we identified the dominant channel unit (pool, riffle or rapid coded as 0,1 or 2 , respectively), and determined bankfull and wet channel widths, streambank height, and the volume of large wood ( $>1-\mathrm{m}$ long and $>10-\mathrm{cm}$ diameter) crossed by transect. The water depth and particle size classes (based on the Wentworth scale) of streambed sediments were determined at each streambank edge, and at three equally distant points along transects. The following indices were used to assess streambed characteristics: mean bankfull channel width (m), the ratio of bankfull width to bankfull depth (determined as the mean water depth + mean streambank height), mean water channel width (m), mean and standard deviation of water depth $(\mathrm{cm})$, mean particle size $\left[\mathrm{M}=\left(d_{16}+d_{50}+d_{84}\right) / 3\right]$, a sediment sorting index ( $\left.\mathrm{S}=d_{75} / d_{25}\right)$, the volume of large wood per meter of transect, and the dominant channel unit. Particle size distribution statistics (i.e., $d_{16}, d_{25}, d_{50}, d_{75}$ and $d_{84}$ ) were determined using the Excel macro Gradistat (Blott and Pye, 2001).

\section{Water temperature and chemistry}

During the litter bag experiment (from mid-September to mid-November), water temperature was recorded every 2 hours using a SmartButton temperature logger (ACR System Inc., Surrey, BC). pH and conductivity were measured in situ on five occasions, and alkalinity, soluble reactive phosphorus (SRP) and nitrate were determined in the laboratory on three occasions. Mean value for each parameter and the standard deviation of daily mean temperature were used in statistical analyses.

\section{Litter bag experiment}

Autumn-shed leaves of alder [Alnus glutinosa (L.) Gaertn] and beech (F. sylvatica L.), a fast and slow decomposition species, respectively, were incubated in the eight stream reaches to determine litter breakdown rates and to sample litter-associated invertebrate assemblages. We used air-dried leaves to make 100 4-g batches of alder litter and 100 2.5-g batches of beech litter. These initial litter masses were chosen to provide roughly equivalent total leaf areas for both species. After re-wetting, leaves were enclosed in 10-mm mesh bags, and 12 litter bags of each litter species were deployed in each of the stream reaches on 16 September 2009. Four control batches of each litter species were kept in the laboratory and used to determine initial organic matter content. Four litter bags were retrieved from each reach on each sampling date (A. glutinosa: 7, 13 and 27 days; F. sylvatica 13, 27 and 53 days). Litter bags were stored individually in plastic ziplock bags at stream temperature during transport.

In the laboratory, leaves were rinsed individually with tap water to remove sediment and exogenous organic matter. Invertebrates were collected in a $0.5-\mathrm{mm}$ mesh sieve and preserved in $70 \%$ ethanol. The remaining litter and control samples of air-dried litter kept in the laboratory were dried at $70^{\circ} \mathrm{C}$ for $72 \mathrm{~h}$, weighed to the nearest $0.01 \mathrm{~g}$ and ground. Approximately $500 \mathrm{mg}$ of ground leaf material was ashed at $550{ }^{\circ} \mathrm{C}$ for $2 \mathrm{~h}$, and weighed to determine its organic matter content. Leaf mass remaining in litter bags was expressed as the ratio between the final and initial litter ash-free dry mass (AFDM). Exponential breakdown rate $(k)$ was estimated by nonlinear regression of the proportion of 

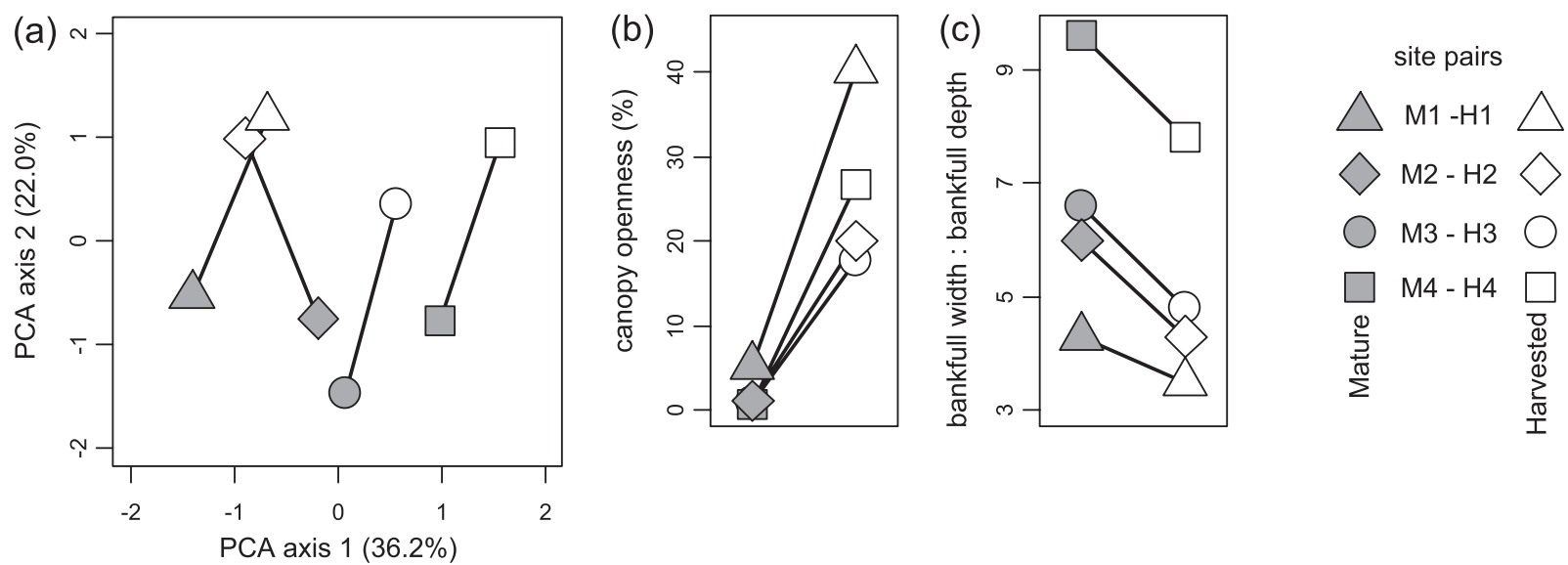

Fig. 1. General stream characteristics of the four pairs of mature forest (solid symbols) and harvested (open symbols) stream reaches. A PCA was used to summarize information from 26 stream abiotic descriptors into two synthetic axes that accounted for $58.2 \%$ of the total variance in the dataset (a). Axis 1 is a gradient of stream size (from left to right) and axis 2 discriminates mature forest and harvested sites. Only two descriptors, the percentage of canopy openness (b) and the ratio of bankfull width to bankfull depth (c) showed a significant difference between reach types.

litter AFDM remaining vs. incubation time (days) using R (R Development Core Team, 2011).

\section{Invertebrate processing}

Invertebrates from litter bags were sorted, counted and identified mostly at family level (taxa listed in Table S1, available online). Reach-scale community analyses were performed using the sum of the individuals found in the 24 litter bags (12 alder +12 beech).

\section{Fish}

Double-pass removal sampling using a Type EFKO FEG 1500 backpack electroshock was conducted in May 2010 along each stream reach to estimate fish density, and to determine fish size and body condition. Individuals were measured to the nearest millimeter (total length) and weighed to the nearest $0.1 \mathrm{~g}$. Body condition was determined as the coefficients of the reduced major axis linear regression of $\ln$ (body mass) vs. $\ln$ (body length) (Cone, 1989). Regression was performed using the smatr package in $\mathrm{R}$ ( $\mathrm{R}$ Development Core Team, 2011). Population size and capture efficiency (95-100\%) were estimated following Carle and Strub (1978), using the FSA (Fisheries stock assessment methods) package in R. The body mass and length of $0+$ age trout were not determined to avoid excessive mortality due to handling, and these were not included in population density estimates due to uncertainties about their capture rate.

\section{Statistical analyses}

A principal component analysis (PCA) was performed to summarize abiotic reach descriptors (see Table S1) and a principal coordinate (PCO) analysis based on BrayCurtis similarity index to assess community structure of litter-bag associated invertebrates (Legendre and Legendre, 1998). Spearman's rank correlation $\left(r_{\mathrm{s}}\right)$ was used to assess the contribution of individual descriptors (PCA) or invertebrate taxa (PCO) to the ordination axes (Zar 1999; Table S1). Exact two-tailed $P$-value was obtained using the package pspearman in $\mathrm{R}(\mathrm{R}$ Development Core Team, 2011).

Harvested (H1-H4) and mature forest (M1 to M4) sites were compared in a pair-wise manner, a powerful approach in studies on control and impact sites. We conducted a paired $t$ test for every single response variable to assess difference between mature forest and harvested reaches (Zar, 1999; Table S1). When analysing invertebrate abundance data, the differences were square-root transformed and the original positive and negative signs were preserved to meet the assumption of paired $t$ test. Quadratic regression was used to investigate the linear and nonlinear effects (Zar, 1999) of canopy openness on the response variables of particular interest that did not respond in a consistent manner.

\section{Results}

\section{Environmental variables}

Streams were circum-neutral or slightly acidic $(\mathrm{pH}=$ $6.2-7.5)$ with relatively low conductivity $\left(41-129 \mu \mathrm{S} . \mathrm{cm}^{-1}\right)$. Nitrate concentrations $\left(954-1343 \mu \mathrm{g} \mathrm{N} . \mathrm{L}^{-1}\right)$ were quite similar across reaches whereas SRP (1.9-17.6 $\left.\mu \mathrm{g} \mathrm{P.L}^{-1}\right)$ and chlorophyll-a content of periphyton (0.19$1.59 \mu \mathrm{g} . \mathrm{cm}^{-2}$ ) varied over a range of nearly one order of magnitude. Mean daily temperature ranged from 10.8 to $12.4{ }^{\circ} \mathrm{C}$ during the breakdown experiment. Wetted channel width and water depth ranged from 1.8 to $3.8 \mathrm{~m}$ and 6.1 to $10.4 \mathrm{~cm}$, respectively. Riffles and rapids were the dominant stream habitats.

A PCA of abiotic reach descriptors condensed 58.2\% of the information into two axes (Fig. 1a). PCA axis 1 

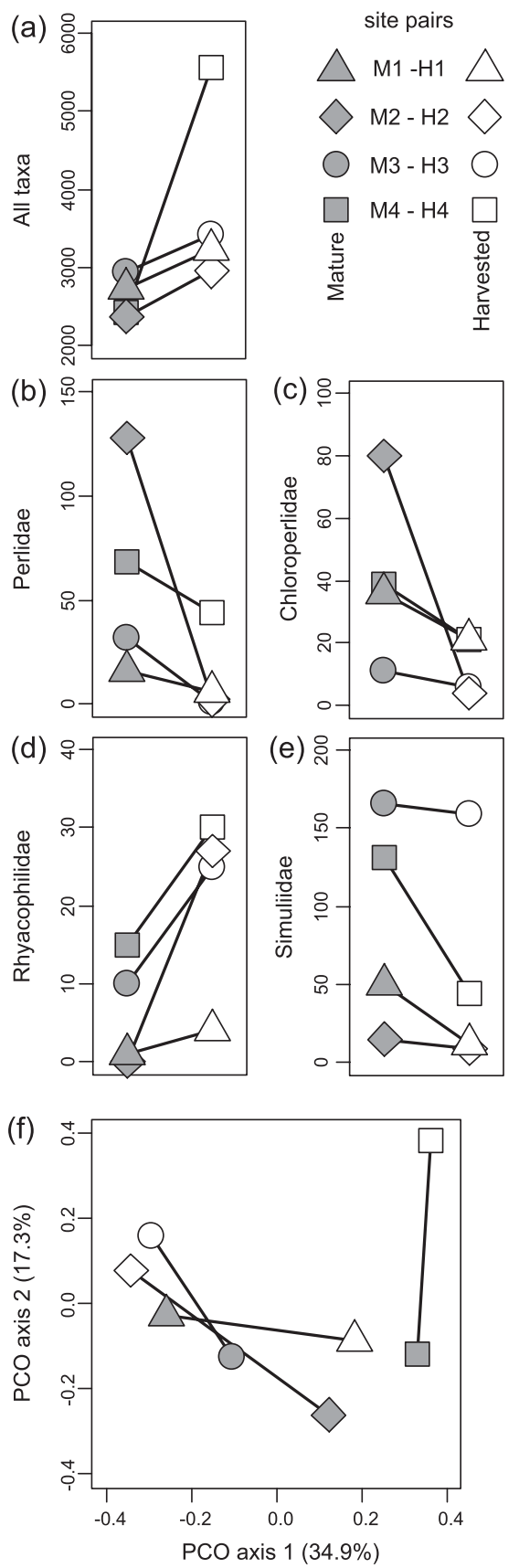

Fig. 2. Invertebrate assemblages in litter bags incubated in four pairs of mature forest (solid symbols) and harvested (open symbols) stream sites. Significant difference between site types was found for total invertebrate abundance (a) and the abundances of four taxa, Perlidae (b), Chloroperlidae (c), Rhyacophilidae (d) and Simuliidae (e). A PCO analysis on abundance data for 42 identified taxa was used to represent Bray-Curtis similarities between the sites on a two-dimensional ordination map (f).

primarily discriminated between the pairs of stream sites, whereas PCA axis 2 separated mature forest and harvested reaches. PCA axis 1 represented a gradient of stream size as indicated by significant Spearman rank correlation between axis scores and catchment area $\left(r_{\mathrm{s}}=0.95\right.$,
$P=0.001)$, wet $\left(r_{\mathrm{s}}=0.90, \quad P=0.007\right)$ and bankfull $\left(r_{\mathrm{s}}=0.81, P=0.022\right)$ channel width, and distance from the source $\left(r_{\mathrm{s}}=0.78, P=0.037\right)$. Altitude $\left(r_{\mathrm{s}}=-0.98\right.$, $P<0.001)$, the ratio of bankfull channel width to bankfull water depth $\left(r_{\mathrm{s}}=0.83, \quad P=0.022\right), \quad \mathrm{SRP} \quad\left(r_{\mathrm{s}}=0.85\right.$, $P=0.015)$, and mean daily temperature during breakdown experiment $\left(r_{\mathrm{s}}=0.74, P=0.046\right)$ also changed along the stream size gradient (PCA axis 1). PCA axis 2 represented riparian forest management as indicated by significant correlations between axis scores and riparian canopy openness $\left(r_{\mathrm{s}}=0.95, P=0.001\right)$, the percent catchment harvested $\left(r_{\mathrm{s}}=0.89, P=0.007\right)$, and harvested area $\left(r_{\mathrm{s}}=0.84, P=0.015\right)$. Canopy openness was always greater in harvested (range: $17.7-40.3 \%$ ) than mature forest (range: $0.6-5.3 \%)$ sites $(t=5.9, P=0.01$, Fig. $1 \mathrm{~b})$. A significant difference between harvested and mature forest reaches was also found for the ratio of bankfull width to bankfull depth $(t=-6.3, P=0.008$, Fig. 1c). Other abiotic variables included in the PCA did not significantly discriminate between reach types $(P>0.09$, Table S1).

\section{Invertebrates}

A total of 42 invertebrate taxa (Table S1) were collected across all stream reaches. Total invertebrate numbers for the 24 litter bags recovered from each site, ranged from 2373 to 5565 individuals. Invertebrate abundance was not linked to cumulated litter AFDM remaining $\left(r_{\mathrm{s}}=-0.31, P=0.46\right)$. Thus, invertebrate abundance in litter bags was determined by factors other than leaf pack sizes at retrieval. The number of individuals captured was always greater in the harvested reach of all site pairs (Fig. 2a). The four most abundant families (Chironomidae, Nemouridae, Gammaridae and Leuctridae), which made up to $75 \%$ of invertebrates captured in litter bags, exhibited variable responses to small-scale forest harvesting $(P>0.23$; Table 2$)$. For instance, Chironomidae were twice as abundant in the harvested reaches $\mathrm{H} 1$ and $\mathrm{H} 4$ compared with their respective control reaches, whereas they were half as abundant in the harvested reaches $\mathrm{H} 2$ and $\mathrm{H} 3$. An exactly opposite pattern of response to forest harvesting was observed for the shredder family Gammaridae, whose abundance was $>7$-fold lower in reaches $\mathrm{H} 1$ and $\mathrm{H} 4$ and $>2$-fold higher in reaches $\mathrm{H} 2$ and $\mathrm{H} 3$ compared with control reaches. Nemouridae and Leuctridae, the other dominant shredders, also showed contrasting positive and negative differences between harvested and mature forest reaches (Table 2). Four non-dominant taxa found at all site pairs showed significant differences in abundance between harvested and mature forest reaches (Figs. 2b-2e). Litter bags in harvested reaches contained lower abundances of Perlidae $(t=-3.6, \quad P=0.038$, Fig. 2b), Chloroperlidae $(t=-3.4, P=0.041$, Fig. 2c) and Simuliidae $(t=-3.2, P=0.050$, Fig. 2e) and a greater abundance of Rhyacophilidae $(t=5.1, P=0.014$, Fig. 2d) than litter bags in mature forest reaches. 
Table 2. Abundance of the four most dominant invertebrate taxa in litter bags incubated in the four harvested (H1-H4) and four mature forest (M1-M4) stream reaches.

\begin{tabular}{llrrrrrr}
\hline Reach code & M1 & H1 & M2 & H2 & M3 & H3 & M4 \\
\hline Chironomidae & 521 & 1257 & 1065 & 575 & 730 & 472 & 1597 \\
Nemouridae & 459 & 868 & 258 & 110 & 449 & 873 & 192 \\
Gammaridae & 773 & 0 & 186 & 1116 & 407 & 1017 & 575 \\
Leuctridae & 439 & 391 & 241 & 272 & 505 & 178 & 3 \\
\hline
\end{tabular}

Table 3. Total length and body condition of age $>1$ brown trout captured in the four harvested (H1-H4) and four mature forest (M1-M4) stream reaches.

\begin{tabular}{|c|c|c|c|c|c|c|}
\hline \multirow[b]{2}{*}{ Reach code } & \multirow[b]{2}{*}{$n$} & \multicolumn{3}{|c|}{ Total length $(\mathrm{cm})$} & \multicolumn{2}{|c|}{ Body condition parameters } \\
\hline & & $\overline{\text { Median }}$ & Min & Max & Slope & Intercept \\
\hline$\overline{\text { M1 }}$ & 22 & 8.7 & 5.8 & 19.8 & 2.9 & -4.2 \\
\hline H1 & 25 & 10.4 & 7.8 & 16.3 & 3.1 & -4.2 \\
\hline M2 & 20 & 11.4 & 8.8 & 16.4 & 3.2 & -4.9 \\
\hline $\mathrm{H} 2$ & 0 & - & - & - & - & - \\
\hline M3 & 20 & 11.9 & 7.8 & 17.6 & 2.8 & -4.0 \\
\hline H3 & 12 & 12.1 & 8.8 & 13.8 & 2.9 & -4.0 \\
\hline M4 & 35 & 10.2 & 8.0 & 15.0 & 3.0 & -4.3 \\
\hline $\mathrm{H} 4$ & 15 & 12.2 & 9.4 & 20.7 & 2.9 & -4.5 \\
\hline
\end{tabular}

Note: $n=$ number of age $>1$ individuals captured. Body condition parameters were the slope and intercept of major axis regression of ln-transformed body mass against ln-transformed body length.

The PCO on Bray-Curtis similarity index revealed site-to-site variability in invertebrate community structure but no clear differences between harvested and mature forest reaches in community structure (Fig. 2f). The scores of PCO axis 1 were positively correlated to Chironomidae abundance $\left(r_{\mathrm{s}}=0.93, P=0.002\right)$ and negatively correlated to the abundances of Gammaridae $\left(r_{\mathrm{s}}=-0.93, P=\right.$ 0.002), Planaridae $\left(r_{\mathrm{s}}=-0.86, P=0.011\right)$, Empididae $\left(r_{\mathrm{s}}=-0.86, P=0.011\right)$ and Scirtidae $\left(r_{\mathrm{s}}=-0.74, P=\right.$ 0.046). Scores of PCO axis 2 were positively correlated to the abundances of Elmidae $\left(r_{\mathrm{s}}=0.98, P<0.001\right)$, Baetidae $\left(r_{\mathrm{s}}=0.79, \quad P=0.028\right)$ and Rhyacophilidae $\left(r_{\mathrm{s}}=0.76\right.$, $P=0.037)$.

\section{Fish}

Our catch consisted almost entirely of native brown trout (Salmo trutta L.), the only exceptions being two gudgeons (Gobio gobio L.) and one brook trout (Salvelinus fontinalis Mitchill, 1814) in reach M3. We captured a total of 149 age $>1$ and 23 young-of-the-year brown trout. No fish was captured in reach H2 (Table 3). Total length of age $>1$ trout ranged from 5.8 to $20.7 \mathrm{~cm}$ (Table 3). Minimum values were significantly greater in harvested than in mature forest reaches $(t=5.0, P=0.037)$, whereas medium and maximum lengths did not display this trend $(P>0.14)$. Trout body condition was similar across all sites (Table 3), and no significant difference was found between stream reach types $(P>0.28)$.

Densities of age $>1$ trout ranged from 0.16 to 0.25 individual per square meter in mature forest reaches, and from 0 to 0.32 individual per meter square in harvested

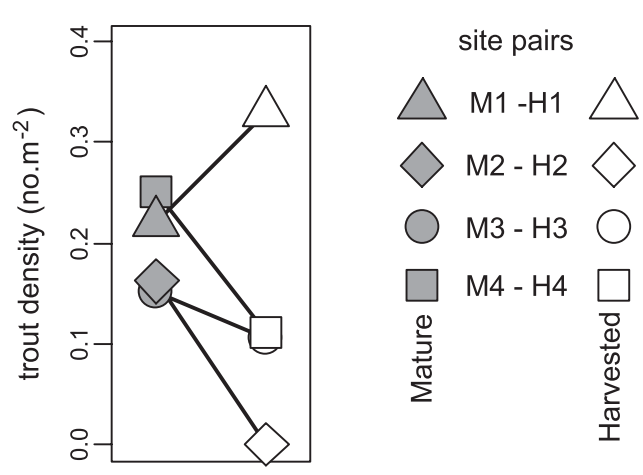

Fig. 3. Densities of age $>1$ brown trout in four pairs of mature forest (solid symbols) and harvested (open symbols) stream sites.

reaches. Densities were lower in harvested than in mature forest reaches in 3 of the 4 site pairs (Fig. 3), but the difference was not significant $(t=-1.0, P=0.407)$. A U-shaped curve was found between canopy openness and trout density (Fig. 4a), indicating that densities might be lowest at intermediate levels of canopy openness (around $20 \%$ ).

\section{Litter breakdown}

No significant trends were observed for differences in the breakdown rates of either leaf species between harvested and mature forest reaches $(P>0.27$, Figs. 5a and $5 \mathrm{~b}$ ). Alder litter breakdown rate was much faster in harvested than in mature forest reaches in stream pairs 2 and 3 (Fig. 5a). This apparently variable impact of smallscale riparian forest harvesting on litter breakdown rates 

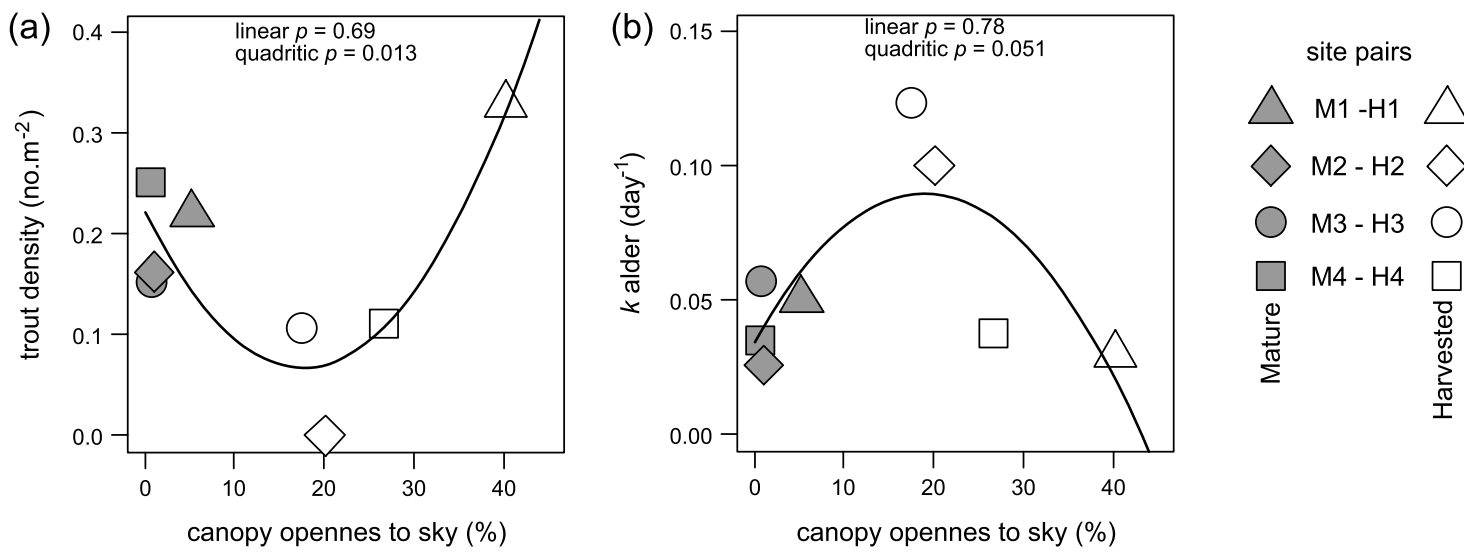

Fig. 4. Brown trout densities (age $>1$ ) (a) and alder litter breakdown ( $k$ ) rates (b) along the gradient of riparian canopy openness formed by the eight study sites. Quadratic regression curves fitted to these data suggest that responses of stream ecosystems to gradual riparian canopy opening are nonlinear.
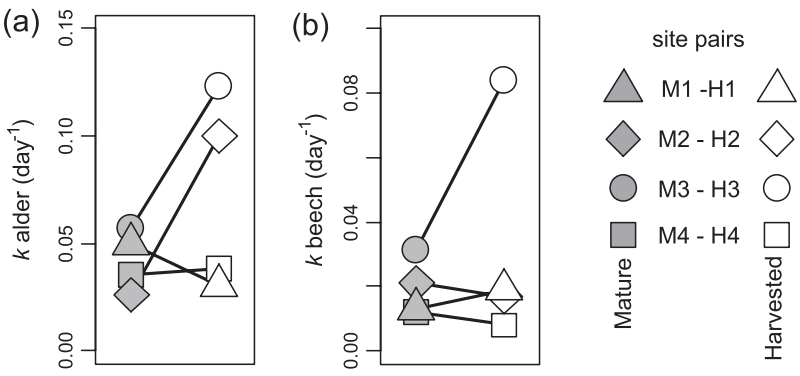

Fig. 5. Breakdown rates $(k)$ of alder (a) and beech (b) litter incubated in four pairs of mature forest (solid symbols) and harvested (open symbols) stream sites.

may be, at least partly, linked to the degree of canopy openness, assuming a bell-shaped relationship between breakdown rate and canopy openness (Fig. 4b). Indeed, the fastest breakdown of alder litter was recorded for intermediate levels of canopy openness (around 20\%). Beech litter usually showed smaller differences within each site pair than alder litter, with the notable exception of pair 3 where beech breakdown was more than twice as fast in the harvested reach $(\mathrm{H} 3)$.

\section{Discussion}

Large-scale forest management and deforestation are known to deeply affect stream habitats including channel morphology, substrate composition, water temperature and chemistry (e.g., Sweeney et al., 2004; Zhang et al., 2009). Our results indicate that small-scale riparian forest harvesting could produce somewhat similar effects on stream ecosystems. Here, the decrease in bankfull width to bankfull depth ratios in harvested stream reaches may be the first evidence of channel incision and narrowing (Montgomery, 1997). Over time, this may result in substrate homogenization and decreased wet channel width (Sweeney et al., 2004; Zhang et al., 2009). Loss of large woody debris and pool area also frequently occurs after riparian forest harvesting (Mellina and Hinch, 2009). However, these were not detected in our study, possibly due to the short time elapsed since harvesting ( $<5$ years).

Litter bags in harvested stream reaches always contained more invertebrates than those in control forested reaches. Previous studies showed similar positive effects of large-scale forest harvesting on benthic invertebrate abundances (Stone and Wallace, 1998; Kiffney et al., 2003; Haggerty et al., 2004). Favorable habitat conditions and greater energy availability may stimulate the production of tolerant invertebrates and thus total invertebrate abundance in recently harvested stream reaches (Ely and Wallace, 2010). Large abundance of generalist consumers such as Chironomidae or Baetidae are commonly reported following riparian forest harvesting (e.g., Wallace and Gurtz, 1986; Kiffney et al., 2003). In addition, catchment level forest harvesting has been reported to adversely affect the abundance and diversity of predatory invertebrates in streams (Zhang et al., 2009). Invertebrate predator vulnerability to forest management was confirmed in the present study by the fact that three of the four families showing significant differences in abundance between harvested and mature forest reaches are predatory invertebrates (Perlidae, Chloroperlidae and Rhyacophilidae; Tachet et al., 2009). The apparent decline of predatory stoneflies (Perlidae and Chloroperlidae) due to riparian forest harvesting suggests that the landscape distribution of these polluosensitive taxa may not be solely determined by water quality (Tachet et al., 2009).

Like most invertebrate taxa, brown trout exhibit variable numerical responses to small-scale riparian forest harvesting. These results are consistent with previous studies reporting either positive, negative or neutral effects of forest harvesting on salmonid population densities (e.g., Northcote and Hartman, 2007). Variable effects of forest harvesting on salmonid densities have been attributed to factors other than riparian forest removal, such as age of logging and management of large wood in streams (Mellina and Hinch, 2009). Moreover, the non-monotonic relationship between canopy openness and trout density in 
our study suggests that salmonids may be quite sensitive to small-scale forest harvesting but their response may also be dependent on post-harvesting canopy openness. Higher minimum values of trout lengths in harvested than mature forest reaches provide further support to the notion that small-scale forest harvesting may not come without consequences for fish.

Litter breakdown data confirm the fact that small riparian forest harvesting can affect stream ecosystem structure and functioning, but the direction and magnitude of these changes are difficult to predict. It seems that even moderate levels of forest disturbance sometimes cause detectable changes in litter breakdown rates as also evident from a few previous studies (Kreutzweiser et al., 2008; Lecerf and Richardson, 2010). Alder litter breakdown rate was $>2$-fold higher in some harvested reaches (H2 and H3) than in corresponding control mature forest reaches (M2 and M3), hinting at a major alteration of stream functioning (Gessner and Chauvet, 2002). Moreover, the lack of overall significant differences between reach types across the four site pairs is in line with previous reports of inconsistent effects of forestry on litter breakdown rates (Hladyz et al., 2010). For instance, studies on litter breakdown responses to large-scale forest harvesting have yielded variable conclusions (acceleration: McKie and Malmqvist, 2009; deceleration: Lecerf and Richardson, 2010).

\section{Implication for stream ecosystem management}

The major impact of large-scale forest harvesting on stream ecosystems has encouraged forest managers to adopt alternative harvest practices such as selective logging, small-scale harvesting or the preservation of riparian buffer strips (Broadmeadow and Nisbet, 2004; Kreutzweiser et al., 2008; Reid et al., 2010). Our study provides some evidence that even small-scale forest harvesting is not without consequences for important structural and functional components of stream ecosystems. However, it is unclear whether the changes observed in our study did differ markedly from changes caused by natural events such as the death or blow-down of a few large trees. Stream resilience to spatially limited alterations of riparian vegetation may thus limit extent and duration of small-scale forest harvesting impacts on streams. Elucidating the sources, extent and duration of such impacts across harvested reaches and natural riparian openings is therefore a major challenge if we are to confirm the usefulness of small-scale forestry and improve forest and stream management schemes.

The variable differences between harvested and mature forest stream reaches indicate that the consequences of small-scale forest harvesting for stream ecosystems can be difficult to predict. Such unpredictability may be partly driven by non-monotonic relationships between postlogging environmental conditions and ecosystem properties (Figs. 4a and 4b). The genuine importance of riparian canopy cover in determining key ecosystem properties needs to be confirmed by further empirical research based on streams spanning a broad gradient of canopy openness and experimental studies examining the interplay between autotrophic and heterotrophic pathways in streams (e.g., Lagrue et al., 2011).

Acknowledgements. This study was supported by funding from ONEMA. We are indebted to S. Blanchet for kindly helping with fish sampling, and to P. Bérard and D. Lambrigot for laboratory assistance. This paper greatly benefited from comments and suggestions by two anonymous reviewers.

\section{References}

Blott S.J. and Pye K., 2001. Gradistat: a grain size distribution and statistics package for the analysis of unconsolidated sediments. Earth Surf. Proc. Land., 26, 1237-1248.

Broadmeadow S. and Nisbet T.R., 2004. The effects of riparian forest management on the freshwater environment: a literature review of best management practice. Hydrol. Earth Syst. Sci., 8, 286-305.

Carle F.L. and Strub M.R., 1978. A new method for estimating population size from removal data. Biometrics, 34, 621-630.

Cone R.S., 1989. The need to reconsider the use of condition indices in fishery science. Trans. Am. Fish. Soc., 118, 510-514.

Ely D.T. and Wallace J.B., 2010. Long-term functional group recovery of lotic macroinvertebrates from logging disturbance. Can. J. Fish. Aquat. Sci., 67, 1126-1134.

England L.E. and Rosemond A.D., 2003. Small reductions in forest cover weaken terrestrial-aquatic linkages in headwater streams. Freshwater Biol., 49, 721-734.

FAO, 2011. State of the World's Forests, Food and Agriculture Organization of the United Nations, Rome.

Gessner M.O. and Chauvet E., 2002. A case for using litter breakdown to assess functional stream integrity. Ecol. Appl., $12,498-510$.

Haggerty S.M., Batzer D.P. and Jackson C.R., 2004. Macroinvertebrate response to logging in coastal headwater streams of Washington, U.S.A. Can. J. Fish. Aquat. Sci., 61, 529-537.

Harrison S., Herbohn J. and Niskanen A., 2002. Non-industrial, smallholder, small-scale and family forestry: what's in a name?Small-Scale Forestry, 1, 1-11.

Hladyz S., Tiegs S.D., Gessner M.O., Giller P.S., Risnoveanu G., Preda E., Nistorescu M., Schindler M. and Woodward G., 2010. Leaf-litter breakdown in pasture and deciduous woodland streams: a comparison among three European regions. Freshwater Biol., 55, 1916-1929.

Kiffney P.M., Richardson J.S. and Bull J., 2003. Responses of periphyton and insects to experimental manipulation of riparian buffer width along forest streams. J. Appl. Ecol., 40, 1060-1076.

Kreutzweiser D.P., Good K.P., Capell S.S. and Holmes S.B., 2008. Leaf-litter decomposition and macroinvertebrate communities in boreal forest streams linked to upland logging disturbance. J. N. Am. Benthol. Soc., 27, 1-5.

Lagrue C., Kominoski J.S., Danger M., Baudoin J.M., Lamothe S., Lambrigot D. and Lecerf A., 2011. Experimental shading alters litter breakdown in streams of contrasting riparian canopy cover. Freshwater Biol., 56, 2059-2069. 
Lecerf A. and Richardson J.S., 2010. Litter decomposition can detect effects of high and moderate levels of forest disturbance on stream condition. Forest Ecol. Manage., 259, 2433-2443.

Legendre P. and Legendre L., 1998. Numerical Ecology. 2nd English edition, Elsevier Science BV, Amsterdam, The Netherlands.

McKie B.G. and Malmqvist B., 2009. Assessing ecosystem functioning in streams affected by forest management: increased leaf decomposition occurs without changes to the composition of benthic assemblages. Freshwater Biol., 54, 2086-2100.

Mellina E. and Hinch S.G., 2009. Influences of riparian logging and in-stream large wood removal on pool habitat and salmonid density and biomass: a meta-analysis. Can. J. Forest Res., 39, 1280-1301.

Montgomery D.R., 1997. What's best on the banks? Nature, 388, 328-329.

Moore R.D., Spittlehouse D.L. and Story A., 2005. Riparian microclimate and stream temperature response to forest harvesting - a review. J. Am. Water Res. Assoc., 41, 813-834.

Northcote T.G. and Hartman G.F., 2007. Fishes and Forestry: Worldwide Watershed Interactions and Management, Blackwell Science, Oxford, UK.

R Development Core Team, 2011. R: A Language and Environment for Statistical Computing. R Foundation for Statistical Computing, Vienna, Austria. ISBN 3-900051-07-0, URL http://www.R-project.org/.

Reid D.J., Quinn J.M. and Wright-Stow A.E., 2010. Responses of stream macroinvertebrate communities to progressive forest harvesting: influences of harvest intensity, stream size and riparian buffers. Forest Ecol. Manage., 260, 1804-1815.

Richardson J.S. and Thompson R.M., 2009. Setting conservation targets for freshwater ecosystems in forested catchments.
In: Villard M.-A. and Jonsson B.G. (eds.), Setting Conservation Targets for Managed Forest Landscapes, Cambridge University Press, Cambridge, 244-263.

Steinman A.D., Lamberti G.A. and Leavitt P.R., 2007. Biomass and pigments of benthic algae. In: Hauer F.R. and Lamberti G.A. (eds.), Methods in Stream Ecology, 2nd edn, Academic Press, Burlington, USA, 357-379.

Stone M.K. and Wallace J.B., 1998. Long-term recovery of a mountain stream from clear-cut logging: the effects of forest succession on benthic invertebrate community structure. Freshwater Biol., 39, 151-169.

Sweeney B.W., Bott T.L., Jackson J.K., Kaplan L.A., Newbold J.D., Standley L.J., Hession W.C. and Horwitz R.J., 2004. Riparian deforestation, stream narrowing, and loss of stream ecosystem services. Proc. Natl. Acad. Sci. U.S.A., 101, 14132-14137.

Tachet H., Bournaud M., Richoux P., Dessaix P. and Pattee E., 2009. Initiation aux invertébrés des eaux douces, Association Française de Limnologie, Thonon-les-Bains, France.

Wallace J.B. and Gurtz M.E., 1986. Response of Baetis Mayflies (Ephemeroptera) to catchment logging. Am. Midl. Nat., 115, 25-41.

Wallace J.B., Eggert S.L., Meyer J.L. and Webster J.R., 1997. Multiple trophic levels of forest stream linked to terrestrial litter inputs. Science, 277, 102-104.

Wipfli M.S., 1997. Terrestrial invertebrates as salmonid prey and nitrogen sources in streams: contrasting old-growth and young-growth riparian forests in southeastern Alaska, USA. Can. J. Fish. Aquat. Sci., 54, 1259-1269.

Zar J.H., 1999. Biostatistical Analysis, Prentice Hall, New Jersey, USA.

Zhang Y., Richardson J.S. and Pinto X., 2009. Catchment-scale effects of forestry practices on benthic invertebrate communities in Pacific coastal streams. J. Appl. Ecol., 46, 1292-1303. 